\title{
Using a political ecology framework to examine extra-legal livelihood strategies: a Lesotho-based case study of cultivation of and trade in cannabis
}

\author{
Julian Bloomer ${ }^{1}$ \\ Trinity College Dublin, Dublin, Ireland
}

\section{Introduction}

The illegal cultivation of cannabis in the southern African state of Lesotho has emerged as a key livelihood strategy that enables smallholder farmers to generate an income from their limited agricultural resources. ${ }^{2}$ Communities in rural Lesotho are faced with severe social-economic challenges, including one of the highest HIV/AIDS prevalence rates in the world (UNAIDS 2006) and a drastic decline in traditional sources of cash income, in the form of remittances from South Africa-based mineworkers. Many indicators point toward a period of accelerated social change in rural Lesotho that is characterised by increased vulnerability and insecurity of livelihoods. Smallholder producers in many less developed regions in the world have frequently experienced increased social, economic, political, and physical marginalisation as a result of global economic integration. For many rural agrarian communities, adapting to changes in the economic and political landscape has meant that subsistence agriculture and wage employment must be combined in increasingly creative ways. Indeed, for many communities, such as former migrant labour reserve colonies like Lesotho, engagement in wage employment through migration became the core economic strategy for rural households in the early twentieth century. In this context, subsistence agriculture became a form of insurance against unsuccessful engagement in the formal and informal wage labour economies. Without cash income, however, households are unable to access basic services or to envisage a positive future. It is in this context that engagement with informal and hidden economies is playing an increasingly important role within rural communities in Africa.

Drawing on frameworks developed in the fields of political ecology, marginalisation and vulnerability studies, as well as livelihoods and agrarian studies, this research examines the illicit cultivation and trade of cannabis in Lesotho, southern Africa. The term extra-legal is adopted in order to highlight the active involvement of official authorities in the trade and the importance of recognising a criminalised network that stretches between formal political actors and those engaged directly in the cannabis trade (J.F. Bayart 1993; J.F. Bayart et al. 1999). An important aspect of the research concerns an examination of how dependence on an extra-legal livelihood practice influences several essential elements of rural life in Lesotho, including the decision-making choices between cultivating cash crops and food crops, the link between cannabis and environmental degradation, and household economics in a community dependent on cannabis income. Beyond this, my research investigates the extent to which different political actors, such as the chieftainship, local government, and police are involved in the trade. Following a brief theoretical overview and presentation of methodology, this article examines the principal issues to emerge from the study before discussing how political ecology can contribute to an examination of extra-legal livelihoods.

\section{Using a political ecology framework for examining illegal crop production}

Political ecology's guiding objective of understanding the complex relations between nature and society through analysing the forms of access and control over resources (R.P. Neumann 2005; P. Robbins

\footnotetext{
${ }^{1}$ Department of Geography, Museum Building, Trinity College Dublin, Dublin 2, Republic of Ireland. Email: bloomejl "at" tcd.ie. The research was supported by a scholarship from the Irish Research Council for Humanities and Social Sciences (2005-2007). I am very grateful for the assistance of numerous people during the research, particularly those in Botsoapa (Lesotho) who patiently answered my questions and placed their trust in me. I would also like to thank David Taylor, Padraig Carmody, David Anderson, and Resetselemang C. Leduka, among others, for their contribution to the research. Thanks also to Tim Collins for his editorial suggestions for this paper. This article is part of the 2008 Eric Wolf Prize special feature, edited by Timothy Collins and Josiah Heyman.

${ }^{2}$ Several different terms for cannabis appear in English literature as well as regional language variations, all referring to the Cannabaceae family. North American literature favours the name marijuana whilst cannabis is mainly used in Europe and among UN agencies. Within the southern African context, dagga (pronounced dac-ha) is the most common term, although specific languages still have their own translations. In Southern Sotho, for example, the formal term is matekoane. This paper will use cannabis, an abbreviation of the species Cannabis sativa, as the default name, dagga and matekoane will also be used when discussing the southern African and Lesotho contexts and in the presentation of the research findings. Hemp is the common name for Cannabis strains cultivated for non-drug use.
} 
2004; M.J. Watts 2000) places it in an excellent position for examining the production and trade of illicit crops. Related themes are already well developed in the political ecology literature. Environmental conflict research has, for example, examined the illegal exploitation of natural resources such as timber (P. Le Billon 2000; L. Tacconi 2007), oil (M.J. Watts 2001), diamonds (P. Le Billon 2001) and the ivory trade (T.N. Håkansson 2004).

Problems arising over access to resources have been a key focus in many political ecology studies, especially those that have examined the often destructive impact of Western-driven conservation policies in many parts of Africa (D. Brockington 2002; R. Duffy 2000; R.P. Neumann 1998; R.P. Neumann 2003). These studies highlighted the importance of illegal livelihood strategies for communities alienated from protected lands. Often livelihood strategies that were formerly legal had become a hidden and clandestine part of their livelihood portfolio.

Alexander Chayanov's (1986) idea of the peasant society's moral economy, developed in the early Twentieth century, and later versions of the theory of everyday peasant resistance (J.C. Scott 1985) are particularly suited to uncover the "motivations, intentions and politics in everyday peasant life" (R.P. Neumann 1998:42). The former theory postulates that due to the inherent risks of subsistence production "social systems of mutual assistance and tolerable exploitation" (P. Robbins 2004:55) are created, in order to allow a degree of flexibility should subsistence production fail. James Scott's theory of everyday resistance highlights the variety of methods, such as the flouting of prohibitions and stealing, that peasants engage in and adopt in order to resist external control. In his examination of responses by Meru people to exclusion from Arusha National Park in Tanzania, Roderick Neumann (1998) documents the various livelihood strategies employed by people to cope, which range from the legal, such as intensifying agricultural production and migration, to the illegal, such as grazing, cultivation and settlement within the park boundaries, and poaching of protected wildlife. Given the strain placed on residents' livelihoods, violations of these laws were seen as morally justified by the perpetrators.

Another important characteristic of political ecology research that is essential in any investigation of illegal crop production is the inclusion of a wider political economy analysis. Given that the trade in illegal crops are normally tied into global distribution networks, it is vital to understand which external factors are driving the trade and to examine power relations between the different actors involved. A wider focus also helps to explain marginalisation that is experienced at the local, national and regional level, an issue that we shall see has particular relevance in the context of Lesotho.

A final point to note is how the marriage between social and ecological studies in political ecology has enabled the development and utilisation of a wide range of research methods. Again the investigation of illegal crop production has much to benefit from broad methodological approaches, as it provides greater flexibility to the research while also strengthening the analysis and its conclusions.

\section{To farm or not to farm? Livelihood diversification and the role of agriculture}

In many parts of rural Africa subsistence agricultural production has long been combined with poorly paid wage labour - often at the household or even individual level (E. Francis 2000). In this economy, male members of the household migrated to work while the responsibility of agricultural production became an additional task for the women who remained behind in the rural home (D.F. Bryceson 2000; F. Ellis 2000a). Recognition of the crucial importance that non-farm income has played in supporting agricultural production is vital to contemporary debates over a perceived crisis in African agriculture. Although notoriously difficult to measure, Martha Alter Chen (2001) estimated that the informal economy accounted for $78 \%$ of all non-agricultural employment, $61 \%$ of all urban employment and $93 \%$ of all new jobs. Access to land alone is often not enough to ensure food security for a household, and other cash income plays a particularly important role, as do a range of social entitlements (H. Bernstein 2005; K. Hussein and J. Nelson 1998).

Failure to recognise the complex linkages between wage labour and subsistence agricultural production has perpetuated the stale assumption made by international institutions and development agencies that Africa is fundamentally an agrarian continent. Thus, its interface with the world market now, and for the foreseeable future, is in agricultural commodity exchange (D.F. Bryceson 1997). Perhaps because the recognition of a process like de-agrarianisation would not sit easily with dominant models of modernisation theory, influential actors in the international development industry, such as the World Bank, continued to generate policy recommendations that were rooted in this simplistic view. As national structural adjustment programmes tightened belts and curtailed government spending on basic services in the 1980s and 1990s, the booming informal sector went un-recognised. Instead antedeluvian notions about the failure of communal land management, championed by Garrett Hardin (1968), boosted calls for privatisation and market solutions, and these influenced agricultural policy (World Bank 1975). This was despite repeated demonstrations that Hardin's argument failed to account for the difference between an open access or freefor-all system with the common situation in Africa: regulated but often often non-codified access to common property (J.T. McCabe 2003). 
Against a background of structural adjustment and liberalisation, much of the research on rural economies, particularly in Africa, has focused on the importance of livelihood strategies and diversification as well as the role of agriculture (e.g., D.F. Bryceson 1999; D.F. Bryceson 2004; D.F. Bryceson and V. Jamal 1997; F. Ellis 2000a; F. Ellis 2000b; E. Francis 2000; K. Hussein and J. Nelson 1998; C. Murray 2002 ; I. Scoones 1998; A. Whitehead 2002). By the dawn of the new millennium, official development organisations, in particular the United Kingdom's Department for International Development, began to propose and then embrace support for 'sustainable livelihoods' development as a key policy goal (D. Carney 1998; D. Carney 1999). The image of the African continent as essentially agrarian-based has influenced the policy recommendations of institutions, donors and organisations involved in rural development in Africa for much of the postcolonial period (F. Ellis 2000a; T. Singh 1990). In the mainstream agricultural development literature, livelihood diversification away from agriculture scarcely features, and non-farm rural growth is regarded as a natural consequence of improved farm productivity.

Livelihood diversification refers to the scope of livelihood strategies that are adopted by an individual, household or community in order to sustain them. Such a process of diversification may have in itself been a reason for declining agricultural productivity as continuing agrarian crises and economic instability forced farmers to direct their attention elsewhere (K. Hussein and J. Nelson, 1998). Even without crisis and instability, many livelihoods both on and off the farm ran to an irregular beat and diversification was perhaps also a response to seasonalities (R. Chambers et al. 1981; F. Ellis 1998). Frank Ellis argues that seasonality is the first of six determinants that affect livelihood diversification, along with risk spreading, the availability of labour markets, credit market failures, investing in order to enhance future livelihood prospects, and diversification (F.Ellis 2000b).

For some, diversification provides an avenue for accumulation, while for others, it is simply a means of coping. Similarly, while diversification is recognised as providing more opportunities to a household, it may also serve to exacerbate inter-household economic differentiation over time (D.F. Bryceson 1999; F. Ellis 2000). Certainly at the poorer end of the economic spectrum it appears that diversification can, for the very poor, mean the difference between survival and destitution. Sara Berry (1989) argues, however, that this does not mean that poor producers will then reinvest their increased incomes into agriculture or other areas but, more likely, they will only be able to meet their subsistence needs.

\section{Livelihoods and cannabis production in rural Lesotho}

In the early twentieth century, Lesotho emerged as one of the key labour reserve colonies in the migrant labour system that was developing in southern Africa. By the mid-1970s, with over 200,000 Basotho men employed in South Africa, rural Lesotho was no longer inhabited by a peasantry dependent on subsistence agricultural production. Instead, rural people constituted a proletariat that "scratched about on the land" (C. Murray 1981:19), dependent on the remittances from South Africa and struggling to maintain the marginal productivity of subsistence farming. In rural Lesotho villages today the deeply entrenched cultural, social and economic ties with migrant labour persist, although the current context often means a partial reversal of gender roles as well as increased insecurity for those, male and female alike, entering either the domestic labour market or the South African one. Income generation in rural Lesotho has traditionally relied on remittances from urban Lesotho and South Africa and this income has been responsible for providing the inputs needed to maintain subsistence agricultural production, especially of the region's staple, maize. Increasing unemployment, primarily as a result of male retrenchment from the mining industry in South Africa over the past two decades has therefore not only resulted in a decline in remittances but also the ability to invest in agricultural production and has therefore been a contributing factor to reducing agricultural yields (C. Boehm 2004).

An illegal crop to cultivate, cannabis was estimated in the late 1990s to be one of the three principal sources of foreign revenue for the country, the others being international aid and remittances from South Africa (L. Laniel 1998:1). The significant contribution of cannabis to some rural household economies was hinted at in nationwide socio-economic surveys (J. Gay and D. Hall 2000; S.D. Turner 2001). Since the 1980s, remittances from South Africa have been in a steady decline as a result of the massive retrenchment of Basotho mineworkers. International aid also declined after the fall of the Apartheid regime in South Africa in 1994, when the international community shifted its focus, and Lesotho lost its status as a frontline antiApartheid state. While there is no official data, other than police seizure statistics (Table 1), all observers with knowledge of rural livelihoods in Lesotho agree that cannabis is the nation's most significant cash crop (C. Boehm 2004; R. Hoover 2001; L. Laniel 1998; M. Thabane 2000; S.D. Turner 2001). Although enjoying what amounts to de-facto decriminalisation, it is still surrounded with a façade of active law enforcement and secrecy at all levels of its cultivation and trade, making any accurate national assessment of its extent and importance as a livelihood strategy very difficult. 


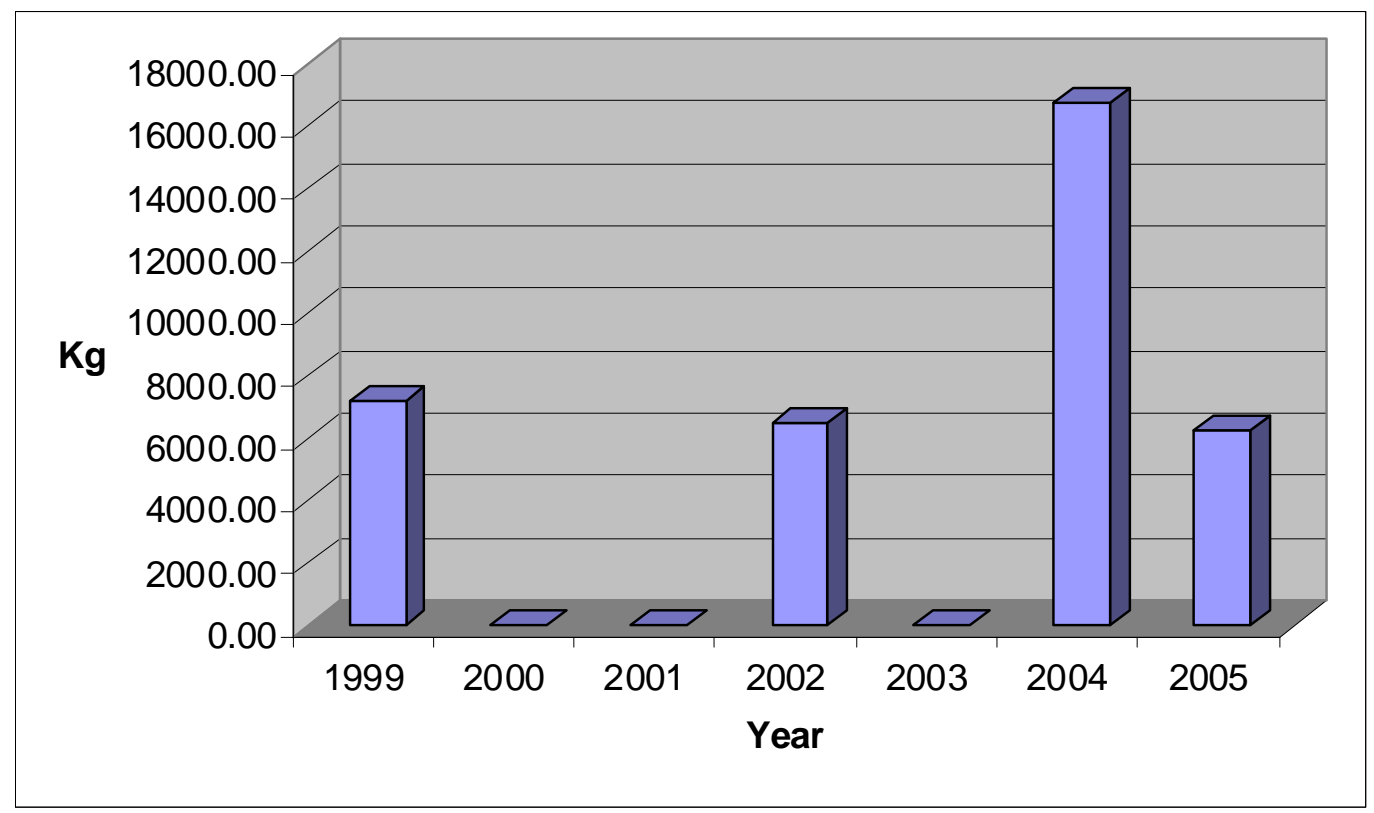

Table 1: Cannabis seizures in Lesotho (1999-2005). No data available for 2000, 2001, 2003. Source: UNODC 2007b.

\section{Methodology}

The research adopted a multi-strategy approach, where qualitative and quantitative methods were combined. This allowed for an in-depth perspective to emerge. Recognising the difficulties of gaining an understanding of the national situation with regard to cannabis production, this research project focused on the cannabis trade in one particular locality in Lesotho. Designing an appropriate methodology for researching extra-legal livelihoods was particularly important given the contentious debates that surround the research of criminalised activities. The main qualitative aspect of the research involved a 12-month period of participant-observation in a rural community that was engaged with cannabis production. Quantitative data collection involved two crop surveys and a household survey that focused on demographic data, crop production figures, and income and expenditure data. All 33 households at the study site participated in the survey. In addition to this, several focus group discussions were held at different times during the research, with members of the community in order to discuss topics of particular interest to the researcher. Interviews with eighteen key informants, such as police officers, chiefs and politicians also provided important sources of information, and along with police statistics, were used to examine the political economy of the cannabis trade from Lesotho to South Africa.

\section{Introduction to the study area}

The village of Botsoapa ${ }^{3}$ overlooks the western lowlands of Lesotho, with the highveld of South Africa's eastern Free State province visible on the horizon (Plate 1). At an altitude of 1,985 metres (6,512 feet), the village is situated in what is usually identified as the northern section of the Foothills agroecological zone in Lesotho (Figure 1). This zone marks the boundary between the lowlands in the west of the country and the high mountains in the centre and east.

Botsoapa had 33 households and a population of 176 people during the fieldwork period. The formal migrant labour system that employed many of Botsoapa's men during the $20^{\text {th }}$ century has been in decline since the late 1980s. Opportunities for wage employment have instead been substituted to some degree by domestic industrial development, such as the textile factories in Maseru and other border towns that mainly employ women, including some originally from Botsoapa. Young men have less possibility of formal employment. South Africa and particularly its construction industry is still the destination for many young men, although without work permits many end up working illegally. One or two have been more successful and have managed to get a formal education and to find work in the formal sector. For those staying in the village, subsistence farming represents one of the primary livelihood strategies for households, with $94 \%$ of households engaged in agriculture. Income is still required, however, for many basic expenses,

\footnotetext{
${ }^{3}$ This is a pseudonym.
} 
such as education fees, transport costs, clothing and health, and basic foodstuffs, as well as the artificial fertiliser and farm implements needed to achieve agricultural production.

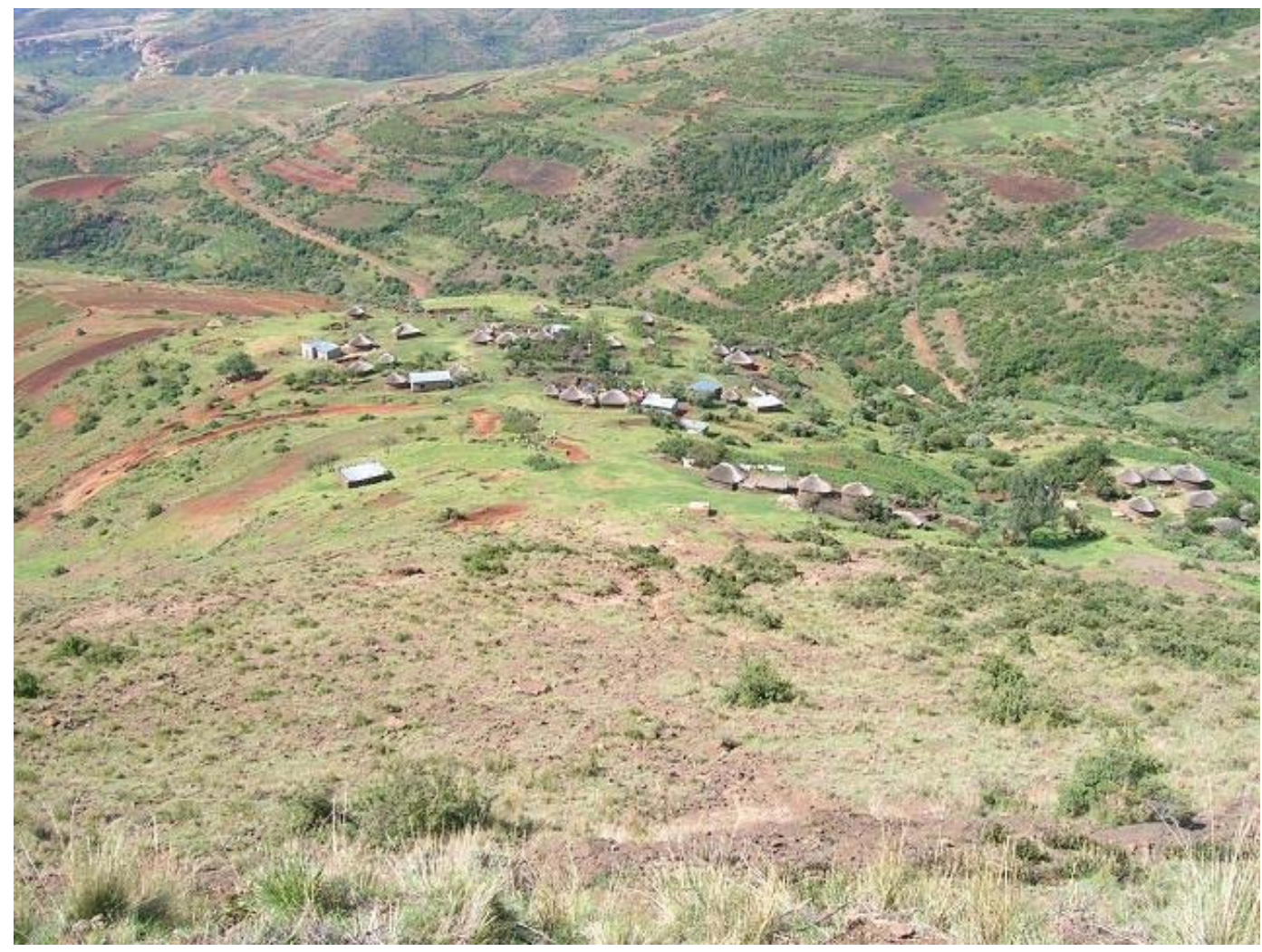

Plate 1: View of Botsoapa (author)

The average household size in Botsoapa is 5.33 persons, which corresponds closely with John Gay and David Hall's (2000:71) regional household size data for the northern foothills region (mean size 5.42) and is identical to the national average. In Botsoapa, 21\% of households were found to have a formal wage earner. Two thirds of employed household members (15\% of the total adult population) worked in Lesotho and the rest in South Africa and abroad. This is slightly higher than the national figure of 12.8\% (Gay and Hall 2000:71), but in the mountains less wage employment is available. Landlessness has traditionally been recognised as an issue of vital bearing on levels of poverty in rural Lesotho. Some $41 \%$ of all households in Lesotho have no fields (Gay and Hall (2000), although less at 28\% of Northern Foothills households. However, in Botsoapa, only $6 \%$ of households lacked cultivable land, suggesting much lower levels of landlessness.

The agricultural season begins in earnest between late August and early September when the fields are ploughed and planted with seeds (Figure 2). Cannabis may be planted up to three times a year in any one field, although one or two harvests are more usual. Seeds saved from the previous harvests are sowed, often with a mixture of artificial fertiliser and manure. Weeding of the majaja or male plants occurs several weeks after planting and the plants are usually harvested three or four months. The plants are predominantly harvested by women who then work beside the field, stripping the buds from the stem and drying the cannabis on a tarpaulin. Table 2 shows the results from the two crop surveys conducted during the fieldwork in Botsoapa. Results from the April 2006 crop survey indicate that approximately 15.3 hectares or 39\% of the total field area in Botsoapa was planted with cannabis. The drop in production between April and December 2006 is due to the drought that was being experienced at the end of 2006. 


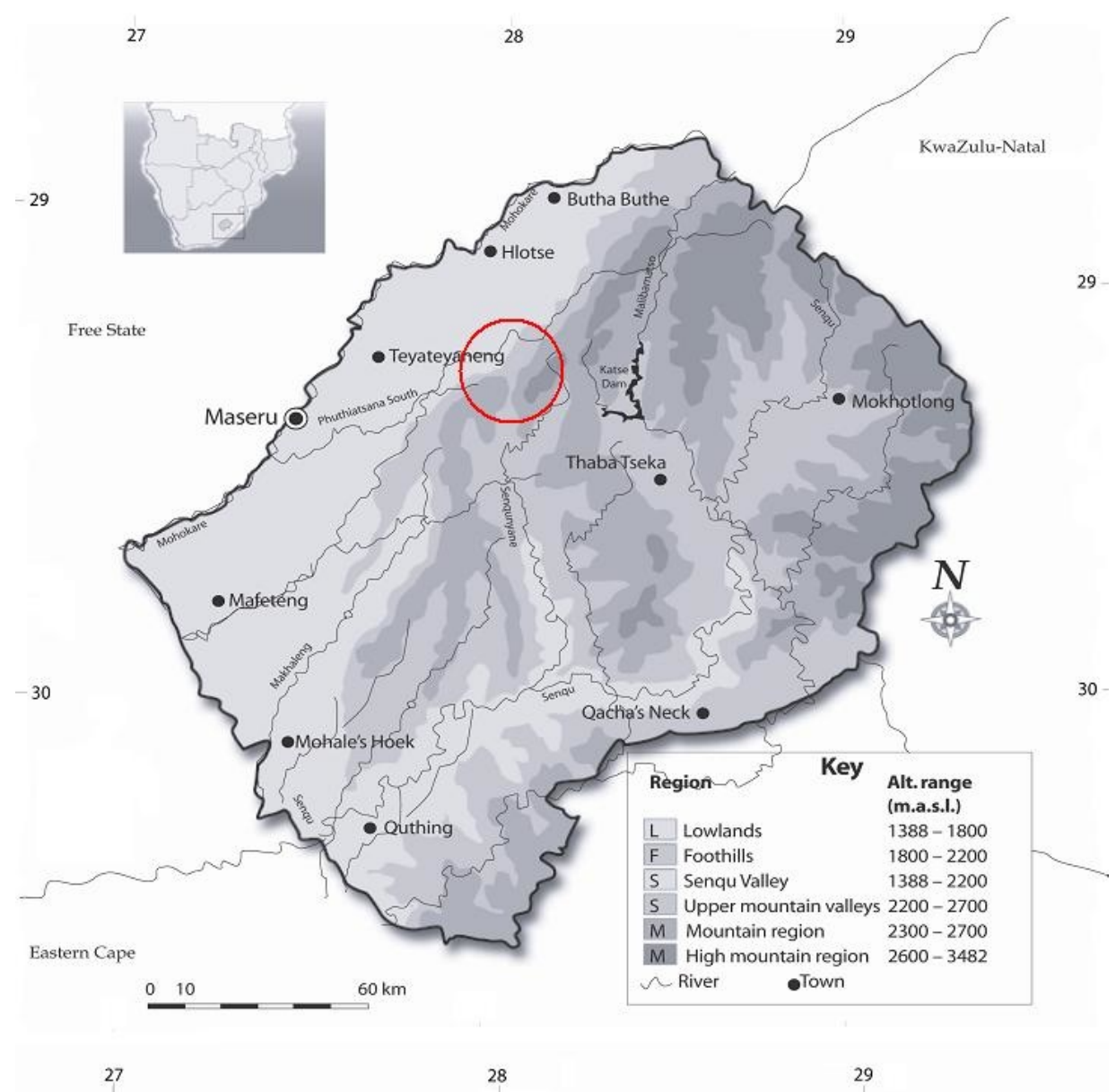

Fig. 1: Topographical map of Lesotho showing main agro-ecological zones with general area of Botsoapa highlighted (adapted from Kobisi, 2005).

\begin{tabular}{|c|c|c|c|c|}
\hline Crops & Apr 2006 (Ha) & Apr 2006 (\%) & Dec 2006 (Ha) & Dec 2006 (\%) \\
\hline Cannabis (alone) & 14.10 & 35.57 & 7.49 & 18.77 \\
\hline Cannabis (mixed) & 1.20 & 3.03 & 3.27 & 8.19 \\
\hline Maize (alone/mixed) & 16.37 & 41.30 & 8.52 & 21.35 \\
\hline Sorghum (alone/mixed) & 4.20 & 10.60 & 4.49 & 11.25 \\
\hline Fallow & 2.45 & 6.18 & 13.16 & 32.97 \\
\hline None & 1.06 & 2.67 & 2.80 & 7.02 \\
\hline Other & 0.26 & 0.66 & 0.19 & 0.48 \\
\hline All & 39.64 & 100.00 & 39.91 & 100.00 \\
\hline
\end{tabular}

Table 2: Crop survey results (April and December 2006). Area and percentage of total cultivated area.

\section{Price fluctuation in the cannabis economy}

Findings indicate that cannabis provided approximately $28 \%$ of the annual income for the village in the 12 months preceding the income and expenditure survey (Figure 3). The importance of cannabis income for individual households varied greatly (Figure 4). Households that relied heavily on cannabis income tended to be the poorer households, while better off households had a higher proportion of non-farm income, 
such as remittances or wage labour. Cannabis production can be viewed more as an extension of subsistence agricultural coping strategies for most households, rather than a core economic strategy for households. This is a scenario that can be seen in many rural communities living in the rural peripheries of southern Africa. In the Richtersveld region of South Africa, for example, Susanne Berzbon (2007) examined the household economy of a community dependent on both wage-labour and pastoralism. While stock farming used to be a core economic activity for the community, its role has shifted to providing insurance against unemployment by increasing diversification and now contributes to subsistence.

\begin{tabular}{|c|c|c|c|c|c|c|c|c|c|c|c|c|}
\hline & Aug & Sep & Oct & Nov & Dec & Jan & Feb & Mar & Apr & May & Jun & Jul \\
\hline \multicolumn{13}{|l|}{ Maize } \\
\hline \multicolumn{13}{|l|}{ Sorghum } \\
\hline \multicolumn{13}{|l|}{ Cannabis } \\
\hline \multicolumn{13}{|l|}{$\begin{array}{l}\text { Cannabis } \\
\text { sale }\end{array}$} \\
\hline \multicolumn{13}{|l|}{ Beans } \\
\hline \multicolumn{13}{|l|}{ Wild moroho } \\
\hline \multicolumn{13}{|l|}{ Peaches } \\
\hline \multicolumn{13}{|l|}{$\begin{array}{c}\text { Garden } \\
\text { vegetables }\end{array}$} \\
\hline \multicolumn{13}{|l|}{ Pumpkins } \\
\hline \multicolumn{13}{|l|}{$\begin{array}{l}\text { Hunger } \\
\text { season }\end{array}$} \\
\hline \multicolumn{13}{|c|}{ Health issues } \\
\hline \multicolumn{13}{|l|}{$\begin{array}{l}\text { Firewood } \\
\text { Collection }\end{array}$} \\
\hline $\begin{array}{l}\text { Livestock } \\
\text { sale }\end{array}$ & & & & & & & & & & & & \\
\hline
\end{tabular}

Fig. 2: Seasonal calendar for Botsoapa.

Cannabis in rural Lesotho may be viewed in a similar way. Faced with declining employment opportunities, cannabis has provided a means to achieve diversification and to provide a subsistence living. During the research, two key issues regarding the market price for cannabis were noted in Botsoapa, namely a seasonal fluctuation in price and a longer term decline in cannabis value. These are both issues that have been the focus of much research with regard to the farming of cash crops. Three factors in particular were identified by farmers in Botsoapa as affecting the price received for cannabis. First, a reduction in cannabis production could cause an increase in price to occur if demand exceeded supply. Second, seasonal fluctuations mean that prices can rise and fall considerably over the course of several months. During the fieldwork, for example, prices fell during the first cannabis harvest of the season, when supply began to meet demand. From a high of M500 (Maloti) ${ }^{4}$ for $25 \mathrm{~kg}$ before harvesting began, to a low of M150 per $25 \mathrm{~kg}$ during harvest time, a large seasonal fluctuation in price was evident. Whether a household made a substantial profit, or whether they merely covered their costs of cultivating the cannabis, was determined by their ability to withhold from selling cannabis during periods of low prices. Third is the effect that a decline in terms of trade has had on the market price received for cannabis over the past two decades. Like many African economies, Lesotho has also experienced a decline in terms of trade, particularly for commodities including cash crops (P. Cashin et al, 2004). The result for cannabis farmers is that they need to sell

\footnotetext{
${ }^{4}$ Maloti (M) is the currency in Lesotho. The exchange rate on $13^{\text {th }}$ February 2008 was 1 Lesotho Loti to $€ 0.09$ (Website: http://www.xe.com). For simplification in this thesis, a notional rounded-off rate of M1 =€0.10 (or €1 = M10) is suggested for ease of calculation. As the Lesotho Maloti and South African Rand (R) are linked at the same rate, the same rate of exchange is used when calculating values present in Rand.
} 
increasing volumes in order to make the same amount of money. This situation, perhaps more than any other, will drive cannabis production upwards as farmers attempt to maintain a steady income.

As a result of seasonal fluctuations in the price of cannabis, farmers are unable to estimate future incomes with any degree of certainty. Instead, they have to wait until harvest time and base their estimates on current market prices. It is not certain either that prices will rise if cannabis is stored rather than sold off immediately. This means there is little incentive to risk storing cannabis in the household, as not only is there an increased chance of it being found by the police, but there is also the possibility that the cannabis could be worth less when the farmer eventually decides to sell. In short, the fluctuating price affects the ability of farmers to plan more than one agricultural season in advance and therefore discourages long-term investments.

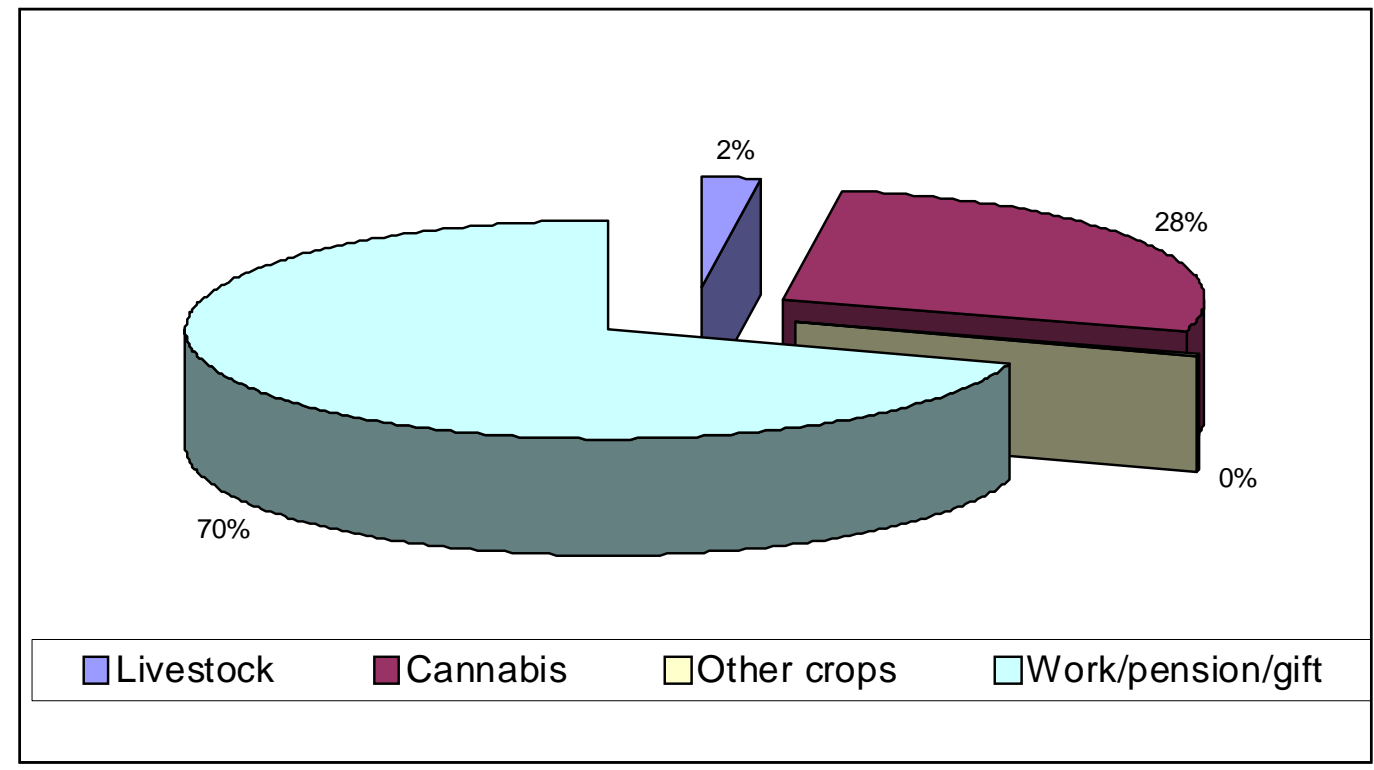

Fig. 3: Breakdown of primary income sources for Botsoapa, 2006. N=33 households.

\section{Income distribution and livelihood diversification}

When the agricultural productivity data from the household survey was examined, most of the production of both cannabis and food crops were concentrated among a small number of the households. In the case of cannabis, the 10 most productive households were responsible for $74 \%$ of the total cannabis production in the village. Yet the important factor was not simply how much cannabis a household was producing, but rather how much income from it contributed to the household's total annual income. It was the households that were completely dependent on cannabis income that were the poorest and most vulnerable in the village and these, unsurprisingly, also tended to be the smaller producers and landholders.

Cannabis cultivation on a commercial scale in Botsoapa can be viewed as a response to converging marginalisations in the ecological, economic, social and political spheres over the last three to four decades. Key issues include the pressure on agricultural land in Lesotho, the impact of the migrant labour system on social life, as well as the economic impact resulting from its collapse, and political instability in Lesotho. Along with more recent developments, such as the increase in levels of HIV-AIDS infection and climate change, rural communities like Botsoapa are experiencing declining employment opportunities and increasingly difficult conditions to practice subsistence farming with any success (C. Boehm 2004; J. Gay and D. Hall 2000; S.D. Turner 2001). Success of subsistence farming, as already noted, has in the past been dependent on remittances and cash inputs to support the cost of agricultural production. Faced with these challenges, cannabis cultivation has offered the opportunity of generating an income from the resources available to almost every household in Botsoapa, namely land. While cannabis is not the only source of income for most households in the village, it is perhaps more reliable than the prospect of waged work, for example, given current economic conditions. 


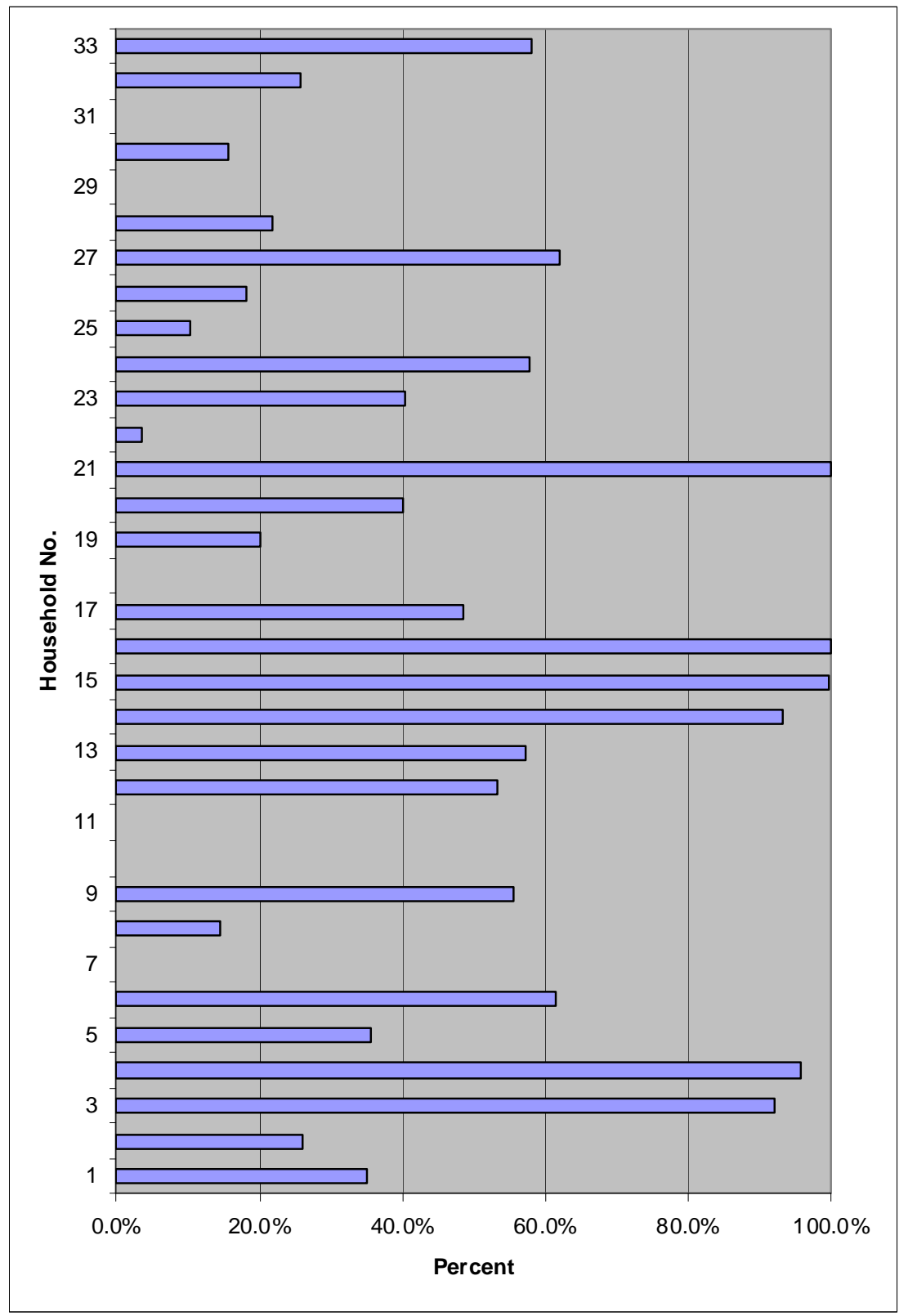

Fig. 4: Cannabis income as a percentage of total household income, 2006. N=33 households.

\section{Gender and cannabis}

Lesotho's involvement as a labour reserve colony in the migrant labour system, and the impact that this system had on women who predominantly remained in the rural areas, has been the subject of detailed research, especially between the 1970s and mid-1990s (e.g., E.A. Eldredge 1991; M. Epprecht 1995; Gay 1980; ISAS 1993; A.C. Langston 1993; C. Murray 1981; A.D. Spiegel 1980). The role of women in agriculture became so prominent that it has been said that the regions supplying migrant labour experienced a feminisation of agriculture, a phenomenon that has been viewed alternately as a liberating event for women and their management of the household economy, and conversely as a further burden to bear (F. Ellis 2000; E. Gordon 1981).

The socio-economic landscape in Lesotho has changed enormously over the past two decades with the large-scale retrenchment of migrant labourers back to Lesotho. Rural villages, such as Botsoapa, no longer have the majority of their male population going to work in South Africa. While some young men still venture across the border in search of work, they can usually only obtain work when the absence of valid 
permits is overlooked, as these are difficult to obtain. A more common occurrence is for young women to go to the urban centres in Lesotho, particularly Maseru, to seek work in the textile factories. Low average incomes in the factories and a relatively high cost of living in Maseru, however, means that remittances to home villages are often very small, if they are received at all. More men are engaging in agricultural production in recent years (C. Boehm 2004), but some tasks are still regarded as the responsibility of women, particularly weeding.

The cultivation of cannabis did not emerge as being very different from that of other crops, in terms of the gendered division of labour. Like other crops, men were responsible for the preparation of the land, particularly when cattle were required to pull the plough and the planter. Women tended to be more involved in weeding and harvesting, even in cases where cash payments were being offered for these activities. Outputs from the cultivation of cannabis and food crops differ, however, with the latter providing food for the household and the former providing income. While relatively little dispute may occur over the allocation of resources yielded by the cultivation of food crops, controlling incomes to the household equates with having influence over household decision-making. Of course, disputes over the control of income vary in different households. However, according to observations made during the research, many men still wish to be in control of household income. During the era of migrant labour, households growing cannabis would have had two sources of income, one from the mines and a second from the sale of cannabis, with women commonly controlling the income from cannabis, because the latter could be concealed from absent husbands. With the presence of the men in the villages now, however, such evasion is not possible without either an agreement being made or a dispute occurring. Although it is only possible to speculate on the effects of a greater involvement by males in the control of household income, they may include a decline in the effective planning and management of a household budget, since in Lesotho, as in other Less Developed Countries (LDCs), women are often the ones responsible for the purchases of household items and other costs associated with the household and children.

\section{Cannabis cultivation: degradation and decision-making}

A recent UN resolution on cannabis in Africa posited that increased cultivation of cannabis has led to accelerated soil erosion, primarily due to the extensive use of fertilisers, overexploitation of the soil and the destruction of forests as a result of an increase in cannabis fields (UNGA 2004). While this has been the scenario experienced in some cannabis producing areas of Africa, most notably in the Rif Mountains in Morocco (J.R. McNeill 1992; H.M. Moore et al. 1998; UNODC 2007a), there are no studies of sufficient depth or duration to make this continent-wide assumption. While this project did not employ a specific methodology to examine rates of soil erosion, observation of the study area and evidence gained during informal interviews provides some perspective on the issue. First, issues like the encroachment of cannabis fields onto marginal land and steep, unstable slopes, was the result of an increase in field area rather than a direct result of degradation caused by the planting of cannabis. While a decline in the terms of trade for cannabis may have been partly responsible for an increase in cannabis production, any use of marginal land, regardless of the specific crop, may have caused this situation. Indeed it could be argued that cannabis, by providing increased ground cover in comparison to the dominant food crops found in Lesotho, actually prevents soil erosion. Similar plants to cannabis, such as sunn-hemp (Crotalaria juncea L.), have been found to provide excellent ground cover and reduce rates of erosion when combined with careful land management practices (K.S. Balkcom and D.W. Reeves 2005; USDA 1999). Of course, it is very difficult to determine the factors that have driven increased cultivation on marginal land in villages, such as Botsoapa, and impossible to state that expansion was motivated solely by cannabis rather than other crops.

A more serious aspect of cannabis cultivation in Botsoapa may be the implications of a decline in plant productivity. Anecdotal evidence gathered during the research suggests that declining plant yields and the increased farming of marginal land may be related, with the overall decline in yields from cannabis plants contributing to increased need for the farming of marginal land. Farmers growing cannabis in Botsoapa said that a noticeable decline in average plant size had occurred over the previous three decades since cannabis production first expanded. Such a decline in plant size and yield is likely a result of reduced soil fertility. The results from the two crop surveys conducted during the fieldwork demonstrated that practices such as crop rotation were limited, with just over $17 \%$ of fields in Botsoapa having their crops rotated with another crop between the two seasons. Monocropping was also common, with nearly $36 \%$ of all fields having the same crop as recorded during the previous survey. This could have been higher had the rainfall been less variable in the second survey. If these findings are part of a longer-term trend of limited crop rotation and continual monocropping, then such practices may have contributed to a decline in soil fertility over the years and a corresponding decline in yield.

Relatively little increase in the overall cultivated area in Botsoapa over the past 25 years is evident from a comparison of spatial data, with an increase of just over $1 \%$ in total field area during that time. A cause of concern, however, is that the increase occurred on the only land remaining for cultivation, namely the very steep slopes that rise behind the village (Plate 1). These new fields were normally used for cannabis cultivation rather than food crop production. While farmers in Botsoapa recognised that the productive lifetime of these fields is limited, as they are particularly susceptible to erosion, there is no other land

Journal of Political Ecology $\quad$ Vol. 16, 2009 
available. As cannabis yields decline, larger areas of land need to be planted in order to maintain output. Providing the price of cannabis remains stable, failure to tackle a decline in output will result in a decline in income from cannabis for the household.

A common concern encountered in the literature, which deals with cannabis in Africa, is that an increase in cannabis production will lead to a decrease in food production as a result of pressure on available land (J. Cilliers 2001; INCB, 2004; A. Labrousse, 2003). Such an occurrence, it is argued, is particularly harmful when it occurs in subsistence farming communities where a decline in food production may result in poorer nutrition, as alternative food supplies are often too expensive for many households.

Data from the crop surveys showed cannabis and the dominant food crop, maize, covering a similar area. In the April 2006 survey, cannabis accounted for 38.6\% of the land planted, while maize accounted for $41.3 \%$ (Table 2). Closer scrutiny of the data showed that although there was variation between households in how much land they allotted to each crop, they generally attempted to strike a balance between the two. During the fieldwork, cannabis farmers who were queried on this issue consistently recognised the importance of growing food crops as well as cannabis. The survey also revealed, however, a large shortfall in overall food supplies for Botsoapa, which suggests that households purchase much of the food they require, and findings from the household survey support this view. So while most households are not food sufficient, they attempt to strike a balance between food and cannabis production, thus minimising the amount of food that will have to be purchased.

\section{Local governance and extra-legal livelihood strategies}

The chieftainship, as the traditional form of local governance, has been strengthened rather than weakened by its engagement in the extra-legal cannabis economy. This is most likely a direct result of the disengagement of cannabis growing areas with central government and its representative authorities, such as the police and the recently established local government councils. Fearful of the power of these authorities to restrict the cannabis trade, the community in Botsoapa has looked inward during times of conflict resolution, using the chieftainship structures to assist in arbitrating disagreements. Some of the conflicts observed during the fieldwork were serious issues, involving cases of domestic abuse as well as violent outbreaks resulting from disagreements over reserved pasture. In a normal situation, these issues would have involved the police, but as a result of the cannabis trade, people in Botsoapa were afraid of police involvement in village affairs and turned to the chieftainship for support. The pitso, or community meeting, was one of the key mechanisms used to discuss and reach agreement over how disputes should be dealt with. At these meetings, the community openly debated the risks of involving government authorities in disputes and made decisions based on the majority viewpoint. Therefore, while engagement in the cannabis trade has, to some extent, disenfranchised the community from central government, it has also enabled the community to retain traditional mechanisms, such as the pitso, in the local decision-making processes.

The chieftainship has at least three factors in its favour in comparison to the local government council. First, the chiefs live in the communities they are working with, and they too depend on income from the cannabis trade. Indeed in Botsoapa, the village headman was the largest producer of cannabis in the village. While members of the local council were also engaged in the cannabis trade, they are under more pressure to observe the authority of central government when they are acting in their official capacity ${ }^{5}$. In contrast, the chiefs are primarily answerable to the hierarchy in the chieftainship. In the case of Botsoapa and Mapoteng, this hierarchy was found to be at least neutral to, if not outright supportive of, the cannabis trade. Second, a chief's power base is the community that they serve rather than central government. While the local council is viewed suspiciously as an extension of central government, people believe that they have less to fear from the chieftainship. Evidence from Botsoapa clearly supports Tim Quinlan's (1995) assertion that the chieftainship is the institutional focus of rural struggles over how external policy and economic forces are assimilated into local society. Third, there is no requirement of a chief to intervene, officially, in a dispute in their area. For example, the village headman in Botsoapa was fully aware of, indeed participated in, the establishment of unregistered fields on marginal land and steep slopes. Although these fields were beyond his area of administration, he was still able to engage in matters of arbitration unofficially, a position that the local council would not have been able to take on easily, due to their physical distance from the community and their accountability to central government.

The tendency in local governance, then, is that the people chose the chieftainship as a known, although not necessarily trusted, entity. In contrast, the local government council, as a political entity, is perceived as being removed from the realities of what engagement in the cannabis trade entails. It is viewed with suspicion and regarded as an agent of central government. One important issue that these findings raise is that if any strategy is to be negotiated between central government and cannabis producing communities

\footnotetext{
${ }^{5}$ During a visit to a local councillor's household in a neighbouring village, the author witnessed large of amounts of cannabis growing in the household's compound.
} 
for the future of cannabis production, then the chieftainship will play a key role in facilitating such negotiations. If the chieftainship were to be sidelined, then interaction with the community would be particularly difficult, with high levels of distrust and suspicion existing on both sides. Another key issue concerns whether a local government council will ever be able to govern in an area dependent on an extralegal livelihood strategy, unless they too engage in the trade. Finally, the presence of the cannabis trade appears to have strengthened local decision-making and traditional forms of governance in favour of those put forward by national government. Undoubtedly there are valuable lessons to be learned from the experiences of communities, such as Botsoapa, that have had to deal with local governance issues from within rather than expecting the support of the state.

\section{Police and the cannabis trade}

Laurent Laniel's (1998) observation that the cannabis trade in Lesotho enjoyed de-facto decriminalisation is supported by this study. However, the cannabis trade is able to function as much from the active participation of authorities in the trade, than simply as the result of official leniency. The significance of this finding is that cannabis probably only enjoys such decriminalisation as long as authorities can profit from the trade. Any serious attempt, for example, to investigate and curtail the practice of corruption amongst the authorities involved, particularly the Lesotho Mounted Police Service (LMPS), would likely have a negative effect on the ability of farmers and smugglers to conduct effectively the cannabis trade in Lesotho. Both cannabis farmers and smugglers would feel the impact if the police and judicial system properly applied penalties, such as fines and the confiscation of cannabis.

Seizures of cannabis and charges relating to the cultivation and trade in cannabis were found to be consistently lower in Lesotho than those of neighbouring South Africa. The conclusion is that different attitudes prevail amongst the police forces in the two countries with regard to the enforcement of legislation that prohibits the cultivation and sale of cannabis. Police interviewed in Lesotho readily admitted that cannabis was not a priority for the LMPS, citing a lack of resources as the main reason why more serious crimes had to be prioritised over cannabis. Yet for the police in the neighbouring South African Province of the Free State, the cannabis trade was identified as their top priority, particularly in the eastern Free State, where the Province borders Lesotho. A recent report by Andrew Faull (2007) on corruption in the South African Police Service (SAPS) reveals that measures to reduce corruption have been largely unsuccessful todate, although new initiatives to tackle corruption are planned. Transparency International publishes an annual global corruption barometer, based on citizen perceptions of corruption. Outside of Africa, politicians are consistently ranked as the most corrupt state actors, yet within Africa, it is always the police (Transparency International 2005). South Africa is unique, with both police and politicians ranked first, implying a network of political-criminal corruption.

Differing perspectives on the cannabis trade between the LMPS and SAPS partly reflects the political pressures placed on these police forces. One of the chiefs in Lesotho who was interviewed during the research readily admitted to asking the police force to be lenient on cannabis farmers in the Mapoteng area. If such requests were heeded by the LMPS then this would demonstrate the power that the chieftainship can exert over policing of the cannabis trade. Similarly, there is little incentive for politicians in rural Lesotho to demand a harsher approach to dealing with the cultivation of and trade in cannabis. With large sections of the rural population dependent on income from cannabis, such a stance could well lead to voters turning against politicians who advocate a more severe treatment of those caught breaking the law.

In contrast to Lesotho, there is significant political pressure in South Africa from those affected by the negative impacts of the cannabis trade. Crime in South Africa is a very important political issue and drug trafficking is no exception (A. Faull 2007). Urban populations in South Africa demand police action to reduce activities relating to the cannabis trade, including car theft and gun crime. In rural areas, such as along the eastern Free State borderline, farmers constitute an important lobbying group with a powerful influence in the Province and at national level. These farmers experience negative impacts of cannabis smugglers crossing their farmland, including the destruction of fences, theft of property, and even direct intimidation if they report the smugglers to police. Lobbying by agricultural groups has undoubtedly ensured that the policing of the borderline remains a priority for the Government and its security forces.

The different perspectives shown towards the policing of the cannabis trade in Lesotho and South Africa by the LMPS and SAPS clearly demonstrates the impact of the trade at different points along the cannabis commodity chain. In Lesotho, the police are fully aware how cannabis supports rural livelihoods by providing an income for cannabis producing communities. Although there are associations made between cannabis and other criminal activities, such as stock theft and gun running, in general the impact from the cannabis trade on crime in Lesotho appears to be relatively minor. Conversely, South Africa is the final destination for much of the cannabis cultivated in Lesotho and the country experiences increased criminal activity as a result of the cannabis trade in part, no doubt, because of the far higher value of cannabis towards the end of its commodity chain. Some of the car theft in South Africa can be attributed to the need of smugglers to transport cannabis from Lesotho to urban areas of South Africa. Other related activities, such as theft to fund cannabis consumption and perceived links with gun crime, ensure that the police are under pressure from the public to curtail the trafficking of cannabis into South Africa. On the basis of these

Journal of Political Ecology $\quad$ Vol. 16, 2009 
findings it can be suggested that, in general, the LMPS view cannabis as an illegal activity, yet one that has positive livelihood implications in Lesotho. In contrast to the LMPS, members of the South African police who were interviewed, clearly view the trade as a criminal activity that needs to be curtailed, especially because of its linkages with other criminal activities in South Africa.

\section{Development assistance and governance in Botsoapa}

The study has raised at least three important issues that need to be considered with regard to how development assistance is provided in areas dependent on income from extra-legal livelihood strategies. ${ }^{6}$ The first issue concerns the categorisation of households in terms of income and resources. None of the previous methods used by non-governmental agencies to identify vulnerable households in Botsoapa considered income from cannabis production in their assessment of household resources. There are obvious reasons why the topic of cannabis income would be avoided, including the problem of false or underreporting on the part of householders if questioned about cannabis income, as well as political sensitivities. The fact remains, however, that household economy profiles are ignoring a resource that is responsible for approximately $27 \%$ of the total income received in this village alone.

A second issue that emerged from the study concerns the value to a community of development projects in which labour contributions are required on a frequent basis. During the research in Botsoapa, participating householders received food supplements in exchange for labour. Labour was used to establish three pilot fields where conservation agriculture was being practiced. In a community that is partly dependent on cash crop production, however, there is a need for clear policies in order to minimise the potential negative impact that may occur when labour is required elsewhere. While food for work schemes can be successful, there are issues that need to be considered carefully in order to minimise any negative impacts, such as encroaching on limited labour availability and reducing already scarce land resources (C. Barrett et al. 2004).

A third issue concerns the potential reluctance of people who are involved in extra-legal livelihood strategies to become engaged with government agencies. While the community in Botsoapa was largely positive about the involvement of NGOs in the village, there was a reluctance to engage with government agencies, especially when matters involving improved infrastructure, such as roads, have been proposed. The feeling in the community, as expressed by the sub-chief in Ha Mantsi during an interview, is that improved roads would also mean an end to the cannabis trade:

You know matekoane is good but it still has a problem...people think that it's not wise having roads because it will bring the police closer to them. But still, alternatively, or I will put it another way, their buyers will reach them easily. What I appreciate is this, it will be alright. Although our people growing matekoane will not be happy! (N. Sekhomo 2006)

Improved roads would allow easier access for vehicles, especially the police, and enable the government to more effectively monitor areas where cannabis is grown. While the logic of this argument might appear sound, it fails to reflect the current situation, whereby the police and other government authorities are fully aware of the extra-legal activities taking place in Mapoteng. It could also be argued, as indeed the sub-chief did, that improved roads would also allow improved access to smugglers. An important factor relating to this issue is the success that a new local government has in gaining the trust of the communities that it represents. Unfortunately the signs from neighbouring countries that have undertaken similar initiatives on decentralisation are not promising. According to Richard Tambulasi and Happy Kayuni (2007), for example, who evaluated the first four years of a new local government system in Malawi, the creation of local government offices increased opportunities for corruption, mismanagement and loss of trust amongst the local electorate.

\section{A political ecology approach to extra-legal livelihoods: the cannabis trade}

A focus on marginalised populations and the underlying issues that can lead to marginalisation, especially as a result of unequal forms of access and control over resources, has been at the centre of the political ecology framework since its inception (R.P. Neumann 2005; P. Robbins 2004; M.J. Watts 2000). As noted previously, political ecology research has been conducted across a range of natural resource based extra-legal economies. Yet many of these studies are primarily concerned with how these extra-legal economies engage with regional and global political economies, often, it would seem, at the expense of detailing the reality of life in rural communities. With regard to the concept of adaptation, Eric Perramond (2007) argues that events witnessed at the local level often have considerable import that can be missed if the primary focus of researchers is making associations with the larger political economy. While establishing links with the wider political economy is an essential part of examining extra-legal economies, it is also

\footnotetext{
${ }^{6}$ Two NGOs were active in the village, one a locally based NGO and the other an international NGO that had been operating in the area for over ten years.
} 
important that individual research studies engage with local communities and pay attention to events occurring at the local level.

In political ecology research the process of marginalisation is most commonly uncovered by identifying forms of access and control, as well as identifying the key decision-makers (R.P. Neumann 2005; P. Robbins 2004). While my findings did not provide a detailed investigation of the intra-household dynamics concerning the control of cannabis, micro level power structures in the community were identified. First, there was a shift in gender roles in agriculture in the village, with the result that women appear to have lost some of the control that they previously exerted over farm incomes. Second, clear imbalances existed within the community, in terms of the distribution of resources. Maintaining positions of political power appears to play a key role in successful engagement in cannabis production, as the chief's household in Botsoapa was producing substantially more cannabis than other households. Third, traditional political power structures outside the village, in the form of the chieftainship hierarchy, exert considerable influence over those engaging in the cannabis trade. The chieftainship forms the link between those involved in cannabis and central and local government structures. In such circumstances, it is in the interest of the chieftainship to straddle the political divide that exists between the electorate and government, and in so doing strengthening the position of the chieftainship. Finally, the police represent an essential factor in the successful operation of the cannabis trade in rural Lesotho. Only with their tacit involvement can the trade function. Whilst recognising the important benefits of the cannabis trade as a livelihood for farming households, it also appears to be providing many police themselves with the option of an improved livelihood portfolio.

Decision-making amongst farmers is dependent on economic pressures and political contingencies, with the former dictating land management goals and the latter determining land management opportunities (P. Robbins 2004). The important lesson from this is that changing political and economic conditions alter the context of decision-making. As has already been argued, such changes are likely to impact upon the viability of the cannabis trade in Lesotho, therefore having an important influence on its mid- and long-term future.

Although the terminology is not entirely appropriate, Mauricio Rubio's (1997) identification of 'perverse social capital', in the drug producing regions of Columbia, was mirrored in Botsoapa. By engaging in extra-legal livelihoods, communities can be drawn together, motivated by a desire to move beyond the watchful eye of Government officials. In Botsoapa, this resulted in the community assuming responsibility for many issues relating to governance. If a higher authority needed to be consulted, the communities went to the chiefs rather than the local government. Uncovering the dynamics of decision-making is a key strength of the political ecology framework, and is particularly important in situations involving extra-legal livelihood strategies that may become the target of interventionist policies. Efforts to intervene in the opium trade in Afghanistan, for example, have highlighted the importance of understanding these decision-making structures (Mansfield and Pain 2005).

While many extra-legal livelihood strategies attract a variety of public and academic supporters and critics, the politics of drug production control are intensely controversial. David Anderson et al. (2007) have noted how khat has been held disproportionately responsible for a range of social ills amongst users, such as divorce, prostitution, begging and the abandonment of families, as well as psychological dysfunction. It is not only consumers of drugs who are vilified by their association with drugs, but growers too. A common perception, particularly amongst urban dwellers in Lesotho, was that those engaged in cannabis growing were also engaged in a multitude of other nefarious crimes. For example, public opinion in more developed countries about rural drug producers in LDCs demonstrates many similarities to debates over conservation policies. The role that political ecology research has played in challenging prevailing attitudes in the West towards conservation policies in LDCs can also be applied to challenging attitudes, perceptions and knowledge concerning the production of illicit crops. Daniel Brockington (2002), for example, argued that conservation policies based on the preservation of a pristine wilderness have omitted histories of residents and labelled their livelihood activities as damaging. Similar arguments can be made against the attitudes frequently displayed towards those involved in the production of crops like cannabis. Socio-economic circumstances are often overlooked and instead the actions of producers are discussed using moralistic terminology, or by making direct associations between growers and organised crime (D.J. Davids 2002; T.L. Roleff 2004).

Considerable progress has been made in the integration of conservation policies and livelihood concerns in recent years, as well as a refocusing of the conservation agenda towards those most directly impacted (e.g., J. Ghazoul 2007; M. Githiru 2007; D. Kaimowitz and D. Sheil 2007; K.E. Medley and H.W. Kalibo 2007; N. Salafsky 2000). A similar theoretical framework and debate can be usefully applied to issues resolving around drug production in LDCs, with the recognition that if drug resources are going to be removed from these communities, then substitutes must be found prior to their removal, although experiences with crop substitution in other parts of the world demonstrate the difficultly of achieving this transition.

A final point to consider in any issue relating to policy development and extra-legal livelihood strategies is the role of the State and its agents. Indeed the use of the term extra-legal has been justified, based on the belief that the term more accurately reflects the involvement and collusion of the State in

Journal of Political Ecology $\quad$ Vol. 16, 2009 
activities like the cannabis trade in Lesotho. While it is a global phenomenon, there are often greater opportunities for collusion between a state and those engaging in extra-legal activities in LDCs that are highly dependent on natural resource extraction (R. Damania and E. Bulte, 2005; T. Kronenberg 2004 ; C. Leite and J. Weidmann 1999; G. Mock 2003). Shadow economies are functioning parallel to formal economies and often the distinction between government agents and organised criminals becomes blurred and may overlap (J.F.Bayart, 1993). William Reno (1998) argues that much greater attention needs to be paid to these shadow economies. The hidden economy of the cannabis trade in Lesotho clearly demonstrates how important these economies can be, but also their fragility and the vulnerability of dependent individuals and communities.

The methodology and ethical conundra encountered in researching extra-legal rural livelihood strategies, particularly illegal crops, are immense. The study of extra-legal crop production is theoretically challenging, with many issues related to illegal drugs being heavily loaded with value judgements and unspoken assumptions (F.E. Thoumi 2003). During the course of this project judgments and assumptions like these have been encountered amongst colleagues, senior academics, and, less surprisingly, amongst government representatives, as well as members of police forces. The majority of encounters with such individuals has involved a certain level of scepticism and ridicule, ranging from lighthearted banter to serious suggestions that the research was inappropriate or inadvisable. These encounters often result in defensive responses, as well as preventative measures for avoiding confrontation, such as when applying for funding or in requests for letters of support.

The perceptions encountered reflect the diversity of opinions on how the issues of drug production and recreational use should be dealt with in the world today. Amongst those who believe in the regulation and criminalisation of such drugs, there is little agreement as to which strategies are the most effective at either the demand-side, by reducing drug use, or at the supply-side, by reducing drug production (G.L. Fisher 2006). Underneath whatever policy decisions are made are people who, through either necessity or by choice, are dependent on the trade. For those in the former category it is vital that their participation in the process be considered in a humane and sensitive way that also puts preconceived judgements aside.

\section{Conclusion}

The underlying conclusion of this article is that cannabis cultivation in rural Lesotho should be viewed as a coping strategy, as opposed to it being seen as criminal opportunism. Cannabis producing households were generally only meeting their subsistence needs, if even that, with the income they received from cannabis. Any policies that attempt to reduce cannabis production in Lesotho will have a large and serious impact on a crucial coping strategy for marginalised rural households. While nationwide estimates of cannabis production were not a focus of this project, it is clear from secondary statistics that cannabis is being produced in many areas of rural Lesotho. Other potential possibilities exist, such as the legal production of hemp, but they are untested and would be in competition with other countries in the region that are attempting similar schemes.

Political ecology provides a very useful framework for examining drug production as an extra-legal livelihood strategy. The framework emphasises the flows of power between different actors, as well as a focus on global linkages, and these aspects are very important when analysing international drug trades. Similarly, a focus on root causes of marginalisation enables construction of an accurate historical context in which to place the research. This article has attempted to highlight how empirically based research can contribute to studies involving extra-legal livelihoods. There are often important methodological and ethical challenges encountered when conducting studies on criminalised activities, but it can be argued that the benefits accruing from the research outweigh the negative implications if due care is taken.

\section{References}

Alvares, E.H.

1995. Economic development, restructuring and the illicit drug sector in Bolivia and Peru: current policies. Journal of Interamerican Studies and World Affairs, 37(3): 125-149.

Anderson, D., S. Beckerleg, D. Hailu, and A. Klein

2007. The khat controversy: stimulating the debate on drug. Berg: Oxford.

Balkcom, K.S. and D.W. Reeves

2005. Sunn-hemp utilized as a legume cover crop for corn production. Agronomy Journal 97: 26-31.

Barrett, C., S. Holden and D.C. Clay

2004. Can food-for-work programmes reduce vulnerability?, Discussion Paper No.7, Department of Economics and Resource Management, Agricultural University of Norway, Ås.

Bayart, J.F.

1993. The state in Africa: the politics of the belly. Longman: London. 
Bayart, J.F., S. Ellis, and B. Hibou

1999. The criminalisation of the state in Africa. James Currey: Oxford.

Bernstein, $\mathrm{H}$.

2005. Rural land and land conflicts in Sub-Saharan Africa. In Reclaiming the land: the resurgence of rural movements in Africa, Asia and Latin America, ed. S. Moyo, and P. Yeros, 67-101. London: Zed Books.

Berry, S.

1989. Social institutions and access to resources. Africa 59(1): 41-55.

Berzborn, S.

2007. The household economy of pastoralists and wage-labourers in the Richtersveld, South Africa. Journal of Arid Environments 70: 672-685.

Boehm, C.

2004. Fields, mines and garments: production, social reproduction and changing livelihood pathways in lowland Lesotho. Ph.D. thesis, Institute of Anthropology, University of Copenhagen, Copenhagen.

Brockington, D.

2002. Fortress conservation: the preservation of the Mkomazi game reserve, Tanzania. Oxford: James Currey.

Bryceson, D.F.

1997. De-agrarianisation in sub-Saharan Africa: acknowledging the inevitable. In Bryceson, D.F. and V. Jamal, Farewell to farms: de-agrarianisation and employment in Africa, 3-20. Aldershot: Ashgate.

Bryceson, D.F.

1999. African rural labour, income diversification and livelihood approaches: a long-term development perspective. Review of African Political Economy 26 (80): 171-189.

Bryceson, D.F.

2000. African peasants’ centrality and marginality: rural labour transformations. In Disappearing peasantries? Rural labour in Africa, Asia and Latin America, eds. D. Bryceson, C. Kay, and J. Mooij, 37-63. London: Intermediate Technologies Group.

Bryceson, D.F.

2004. Agrarian vista or vortex: African rural livelihood policies. Review of African Political Economy 102: 617-629.

Bryceson, D.F., and V. Jamal, eds.

1997. Farewell to farms: de-agrarianisation and employment in Africa,. Aldershot: Ashgate.

Carney, D.

1999. Approaches to sustainable livelihoods for the rural poor. London: Overseas Development Institute.

Carney, D., ed.

1998. Sustainable rural livelihoods: what contribution can we make?. London: Department for International Development.

Cashin, P., C.J. McDermott, and C. Pattillo

2004. Terms of trade shocks in Africa: are they short-lived or long-lived? Journal of Development Economics 73: 727-744.

Chambers, R., R. Longhurst, and A. Pacey, eds. 1981. Seasonal dimensions to rural poverty. London: Francis Pinter.

Chayanov, A.V.

1986. The theory of peasant economy. Madison: University of Wisconsin Press:

Chen, M.A.

2001. Women in the informal sector: a global picture, the global movement. SAIS Review 21(1): 7182.

Cilliers, J.

2001. Regional conflict and poverty in southern Africa, Institute of Security Studies, Paper presented at a southern African Regional Poverty Network (SARPN) conference held at the Human Sciences Research Council, 26 April, Pretoria, South Africa. 
Damania, R.,and E. Bulte

2005. Resources for sale: corruption, democracy and the natural resource curse. Discussion Paper No.0320, Centre for International Economic Studies: Adelaide.

Davids, D.J.

2002. Narco-terrorism: a unified strategy to fight a growing terrorist menace. Herndon: Transnational.

Duffy, R.

2000. Killing for conservation: wildlife policy in Zimbabwe. Oxford: James Currey.

Eldredge, E.A.

1991. Women in production: the economic role of women in nineteenth-century Lesotho. Signs 16(4): 707-731.

Ellis, F.

2000a. Rural livelihoods and diversity in developing countries. Oxford: Oxford University Press.

Ellis, F.

2000b. The determinants of rural livelihood diversification in developing countries. Journal of Agricultural Economics 51(2): 289-302.

Epprecht, M.

1995. Women's 'conservatism' and the politics of gender in late colonial Lesotho. Journal of African History 36: 29-56.

Faull, A.

2007. Corruption and the South African Police Service: a review and its implications. Pretoria: Institute for Security Studies.

Fisher, G.L.

2006. Rethinking our war on drugs: candid talk about controversial issues. Westport: Praeger.

Francis, E.

2000. Making a living: changing livelihoods in rural Africa. London: Routledge.

Gay, J.S.

1980. Basotho women's options: a study of marital careers in rural Lesotho. PhD dissertation, Cambridge University, Cambridge.

Gay, J., and D. Hall

2000. Poverty and livelihoods in Lesotho, 2000: more than a mapping exercise. Maseru: Sechaba Consultants.

Ghazoul, J.

2007. Placing humans at the heart of conservation. Biotropica 39(5): 565-566.

Githiru, M.

2007. Conservation in Africa, but for whom? Oryx 41(2): 119-120.

Gordon, E.

1981. An analysis of the impact of labour migration on the lives of women in Lesotho. The Journal of Development Studies 17(3): 59-76.

Håkansson, T.N.

2004. The human ecology of world systems in East Africa: the impact of the ivory trade. Human Ecology 32(5): 561-591.

Hall, J.

2003. Africa at large: Farmers find marijuana the most lucrative cash crop. Oslo: The Norwegian Council for Africa. Website: http://www.afrika.no/noop/page.php?p=Detailed/3864\&print=1 Accessed: 08/04/2005.

Hardin, G.

1968. The tragedy of the commons. Science 162: 1243-1248.

Hoover, $\mathrm{R}$

2001. Pipe dreams: the World Bank's failed efforts to restore lives and livelihoods of dam-affected people in Lesotho. Berkeley: International Rivers Network. 
Hussein, K., and J. Nelson

1998. Sustainable livelihoods and livelihood diversification. Working Paper, Institute of Development Studies. Brighton: Institute of Development Studies.

INCB

2004. Annual report 2003. Vienna: International Narcotics Control Board.

ISAS

1993. Women, land and agriculture in Lesotho Institute of Southern African Studies (ISAS), Working paper series No.4. Roma: ISAS, National University of Lesotho.

Kabeer, A.

2007. Mainstreaming gender in social protection for the informal economy. London: Commonwealth Secretariat Library.

Kaimowitz, D., and D. Sheil

2007. Conserving what and for whom? Why conservation should help meet basic human needs in the tropics. Biotropica 39(5): 567-574.

Kobisi, K.

2005. A preliminary checklist of the plants of Lesotho. Southern African Botanical Diversity Network (SABONET) Report No.34. Pretoria: SABONET.

Kronenberg, $\mathrm{T}$.

2004. The curse of natural resources in transition economies. The Economics of Transition 12(3): 399-426.

Labrousse, A.

2003. The development of cannabis production. African Geopolitics 10. Website: www.africangeopolitics.org/show.aspx?articleid=3586 Accessed on: 01/02/2007

Langston, A.C.

1993. The ties that bind: marriage and dependency in Basotho women's lives. B.A. thesis, Department of Anthropology, Harvard University.

Laniel, L.

1998. Cannabis in Lesotho: a preliminary study. Management of Social Transformations, Discussion Paper No.34. Website: http://www.unesco.org/most/dslaniel.htm Accessed on: $17 / 11 / 2004$.

Le Billon, $\mathrm{P}$.

2000. The political ecology of transition in Cambodia, 1989-1999: war, peace, and forest exploitation. Development and Change 31(4): 785-805.

Le Billon, P.

2001a. Angola's political economy of war: the role of oil and diamonds 1975-2000. African Affairs 100(398): 55-80.

Leite, C., and J. Weidmann

1999. Does mother nature corrupt? Natural resources, corruption and economic growth. Working Paper No.99/85, International Monetary Fund. Washington, D.C.: International Monetary Fund.

Mansfield, D., and A. Pain

2005 Alternative livelihoods: substance or slogan? Briefing paper, Afghanistan Research and Evaluation Unit. Kabul: Afghanistan Research and Evaluation Unit.

McCabe, J.T.

2003. Sustainability and livelihood diversification among the Maasai of northern Tanzania. Human Organization 62(2): 100-111.

McNeill, J.R.

1992. Kif in the Rif: a historical and ecological perspective on marijuana, markets, and manure in northern Morocco. Mountain Research and Development 12(4): 389-392.

Medley, K.E., and H.W. Kalibo

2007. Global localism: recentering the research agenda for biodiversity conservation. Natural Resources Forum 31(2): 151-161.

Mock, G.

Journal of Political Ecology

Vol. 16, 2009 
2003. Undue influence: corruption and natural resources. In World Resources 2002-2004: decisions for the earth - balance, voice and power. Pp. 36-37. Washington, D.C.:World Resources Institute.

Moore, H.M., H.R. Fox, M.C. Harrouni, and A.E. Alami

1998. Environmental challenges in the Rif mountains, northern Morocco. Environmental Conservation 25: 354-365.

Murray, C.

1981. Families divided: the impact of migrant labour in Lesotho. Cambridge: Cambridge University Press.

Murray, C.

2002. Livelihoods research: transcending boundaries of time and space. Journal of Southern African Studies 28(3): 489-509.

Neumann, R.P.

1998. Imposing wilderness: struggles over livelihood and nature preservation in Africa. Berkeley: University of California Press.

Neumann, R.P.

2003. The production of nature: colonial recasting of the African landscape in Serengeti National Park. In Political ecology: an integrative approach to geography and environment-development studies,eds. K.S. Zimmerer, and T.J. Bassett, 240-255. London: Guilford Press.

Neumann, R.P.

2005. Making political ecology. London: Hodder Arnold.

Perramond, E.

2007. Tactics and strategies in political ecology research. Area 39(3).

Quinlan, T.

1995. Marena a Lesotho: chiefs, politics, and culture in Lesotho. Unpublished Ph.D. thesis, University of Cape Town, South Africa.

Ranthamane, M.

2004. Land and water management: Lesotho country situational analysis. Southern African Development Community.

Reno, W.

1998. Warlord politics and African states. Boulder: Lynne Reiner.

Robbins, $\mathrm{P}$

2004. Political ecology: a critical introduction. Oxford: Blackwell.

Roleff, T.L., ed.

2004. War on drugs: opposing viewpoints. Farmington Hills, MI: Greenhaven Press.

Rubio, M.

1997. Perverse social capital: some evidence from Columbia. Journal of Economic Issues 31(3): 805-816.

SADC

2004. Statement by the SADC executive secretary at the SADC social security specialists regional conference, November 29, Gabarone, Botswana.

Salafsky, N.

2000. Linking livelihoods and conservation: a conceptual framework and scale for assessing the integration of human needs and biodiversity. World Development 28(8): 1421-1438.

Scoones, I.

1998. Sustainable rural livelihoods: a framework for analysis. IDS Working Paper 72. Brighton: Institute of Development Studies.

Scott, J.C.

1985. Weapons of the weak: everyday forms of peasant resistance. New Haven: Yale University Press.

Sekhomo, N.

2006. Interview with Ntate Sekhomo, the sub-chief of Kueneng, Mapoteng and Bela-Bela, 29 September, Bela-Bela, Berea District (files of author). 
Singh, T.

1990. The great ascent: the rural poor in South Asia. Baltimore: John Hopkins University Press.

Spiegel, A.D.

1980. Rural differentiation and the diffusion of migrant labour remittances in Lesotho. In Black villagers in an industrial society: anthropological perspectives on labour migration in South Africa.

P. Mayer, ed., 109-168. Oxford University Press: Cape Town.

Tacconi, L.

2007. Illegal logging: law enforcement, livelihoods and the timber trade. London: Earthscan.

Tambulasi, R.I.C., and H.M. Kayuni

2007. Decentralization opening a new window for corruption. Journal of Asian and African Studies 42(2): 163-183.

Thabane, $\mathrm{M}$.

2000. Shifts from the old to new social and ecological environments in the Lesotho Highlands Water Scheme: relocating residents of the Mohale Dam area. Journal of Southern Africa 26(4): 633653.

Thoumi, F.E.

2003. Illegal drugs, economy, and society in the Andes. Baltimore: The Johns Hopkins University Press.

Transparency International

2005. Report on the Transparency International corruption barometer 2005. Policy and Research Department, Transparency International. Berlin: Transparency International.

Turner, S.D.

2001. Livelihoods in Lesotho. Maseru: CARE Lesotho.

UNAIDS

2006. Report on the global AIDS epidemic 2006. Geneva: United Nations Programme on HIV/AIDS.

UNGA

2004. Resolution 59/160: Control of cultivation of and trafficking in cannabis. New York: United Nations General Assembly.

UNODC

2007a. Morocco: cannabis survey 2005. Vienna: United Nations Office on Drugs and Crime.

UNODC

2007b. Afghanistan opium survey 2007. Kabul: United Nations Office on Drugs and Crime.

USDA

1999. Sunn hemp: a cover crop for southern and tropical farming systems. Soil Quality Agronomy Technical Note No.10. Auburn: United States Department of Agriculture, Natural Resources Conservation Service, Soil Quality Institute.

Watts, M.J.

2000. Political ecology. In A companion to economic geography, eds. E. Sheppard and T.J. Barnes, 257-274. Oxford: Blackwell.

Watts, M.J.

2001a. Petro-violence: community, extraction, and political ecology of a mythic community. In Violent environments, eds. N.L. Peluso and M.J. Watts, 189-212. Ithaca and London: Cornell University Press.

Whitehead, A.

2002. Tracking livelihood change: theoretical, methodological and empirical perspectives from north-east Ghana. Journal of Southern African Studies 28(3): 575-598.

World Bank

1975. Land policy reform paper. Washington, DC: The World Bank. 


\begin{abstract}
Rural livelihood strategies that engage in criminalised activities and hidden economies are an important, yet understudied, aspect of achieving economic diversification. This paper discusses findings from a project that examined the role and importance of cannabis cultivation, as a criminalised cash crop, in Lesotho. The research employed a multi-strategy approach that combined qualitative and quantitative methodologies. Cannabis income was found to play a very important role in economic and livelihood diversification in the study area. The paper concludes that cannabis production, as an extra-legal livelihood strategy, should be viewed by policy makers using a livelihoods focus, rather than a criminal one, if rural smallholders are not to be further marginalised by drug control policies.
\end{abstract}

Key words: cannabis; Lesotho; political ecology; extra-legal livelihood

\title{
Resumen
}

Las estrategias del medio de vida rural que se involucran en actividades ilegales y en economías ocultas son un aspecto importante, aunque no ha sido estudiado lo suficiente, para lograr una diversificación económica. Este ensayo trata sobre los resultados de un proyecto que estudió el papel y la importancia del cultivo de cannabis como una cosecha ilegal para venta, en Lesotho. La investigación empleó un diseño de estrategias múltiples que combinó metodologías cualitativas y cuantitativas. Se encontró que los ingresos del cannabis juegan un papel muy importante en la diversificación económica y en los recursos en el área de estudio. El ensayo concluye que la producción de cannabis, como táctica ilícita de sustento debe ser vista por quienes elaboran las normas, más bien con un enfoque hacia los recursos, en vez de lo ilegal, si los pequeños agricultores no van a ser relegados todavía más por las políticas para el control de las drogas.

Palabras claves: cannabis; Lesotho; ecología política; medios ilegales de vida

\section{Résumé}

Les stratégies de revenus ruraux qui sont liés à des activités d'ordre criminel et d'économies informelles sont un aspect important, et pourtant non étudié, de la diversification économique. Cet article rend compte des recherches effectuées dans le cadre d'un projet qui a étudié le rôle et l'importance de la culture de cannabis au Lesotho, en tant que revenu d'origine criminelle. La recherche est basée sur une approche multi-stratégique qui combine des méthodologies qualitative et quantitative. Il est démontré que le cannabis en tant que revenu joue un rôle important dans la diversification économique au niveau de la zone géographique étudiée. L'article conclu sur le fait que la production de cannabis en tant que stratégie de revenu extra-légal, devrait être perçue par les gouvernants comme un gagne-pain plutôt que comme une activité criminelle, ce qui permettrait aux petits exploitants agricoles de ne pas être encore plus marginalisés à cause des politiques de contrôle des drogues.

Mots-clés: cannabis; Lesotho; écologie politique; stratégie de revenu extra-légal 